the annual budget is studded with expensive projects (the Superconducting Super Collider, the space station and the Idaho Fast Reactor) which the Congress promptly casts into limbo, at least temporarily. At the very least, the administration would be better able to get its way if it had formed a coherent view of what it wanted. It might even, that way, arrive at wiser goals.

The government of France, which is even newer, is similarly exercised (see page 196), but with characteristically Gallic differences. The Minister for Higher Education and Research, François Fillon, wants to make contracts with research agencies on the basis of an explicit set of priorities to be decided after a period of public consultation. He promises to enliven next spring with public debates along the lines of those arranged by the Socialist government more than a decade ago. That earlier exercise worked well, but largely because one man, Hubert Curien, was the minister in charge for most of the time and had the weight to carry through the strategy agreed. Does Fillon have the stomach for that?

Interestingly, the recent public consultation in Britain was less concerned with content than with procedure, but those who organized the exercise were surprised at the readiness of working scientists to offer opinions for the way in which research support should be organized. That is not at all surprising; do not researchers have a vivid interest in how the money that supports their work is spent? But research goals have yet to be divined, by the as yet untested mechanism of 'foresight' analysis. But in due course, Britain is also promised a research strategy.

What will happen if all three turn out to be the same? That, of course, is the extreme worst case. In reality, for example, neither France nor Britain is likely to decide to follow the United States in spending the best part of $\$ 10$ billion on a new particle accelerator. No formal papers on the topic would be needed to tell them that they cannot afford it, that it would be irrelevant to most other goals and that they are, in any case, committed to sharing in such an enterprise at CERN, the European High-Energy Physics Laboratory at Geneva. What that implies is what strategy-makers everywhere should acknowledge at the beginning of their task: that there is no point in designating as priorities research ambitions for which the facilities do not exist and for which there is no fund of enthusiasm within the research community.

Those are the tests by which the development of governments' strategies for research should be judged. On the face of things, the French device of public consultation about content seems the best, although there are some in Britain who would argue that 'foresight' (which is supposed to entail consultation among knowledgeable people) will have the same effect. At this stage, Gore's plan for the United States seems better attuned to the test of affordability than to an assessment of what the research community is enlivened by. Is he reckoning that the Congress, perhaps deprived of the chance to let big projects swing in the wind for a little while, will provide the research community with a platform for its own opinions? That would be no bad thing.

\section{BBC in trouble}

Britain's best broadcaster may be making a mess of its strategy to win a new charter on favourable terms.

THE British Broadcasting Corporation (BBC) is going through a bad patch from which it may not escape undamaged. The $\mathrm{BBC}$ may be the best broadcasting organization in the world. Certainly it has the reputation of being at once an innovative source of public entertainment and enlightenment and an objective source of information. But the organization has now run into trouble of a kind probably periodically inseparable from its distinctive and even anomalous constitution, but on this occasion exacerbated by its own misjudgements. Especially at a time when there is a need for a wider understanding of the social and economic value of research, an erosion of the competence of the dominant broadcasting organization would be tragic.

The BBC is not a state-controlled organization. Its income of $£ 1.5$ billion odd is rather almost entirely derived from user fees payable by people who own television receivers, who must buy an annual licence. Other smaller chunks of income come from the sale of programmes to other broadcasting organizations and from the Foreign and Commonwealth Office, which makes an annual grant for radio broadcasts aimed overseas. Technically, the British government has no control over the BBC's broadcasting, which is the responsibility of its staff, themselves responsible to a board of governors, mostly lay-people of miscellaneous interests. But in reality, the government has three sanctions; it appoints the governors, it agrees (or disagrees) annually with the BBC's proposal of what the annual licence fee should be and, periodically, it has to rewrite the charter that allows the BBC to collect its chief source of revenue.

The benefits of this arrangement are that the $\mathrm{BBC}$ is in day-to-day control of what it broadcasts. The snags, as some see it, are the same; the BBC is not 'accountable' in any fashionable sense of the word. Politicians are especially offended that the BBC has an honourable record of showing up bluster for what it is. So it is not surprising that for the best part of a decade, there have been mutterings that the new charter, which must be agreed before the end of 1996, would be a truncated version of that now in effect.

Unfortunately the BBC's management seems bent on winning the battle for a continuation of the present arrangements by conceding the complaints. Able people have been turned prematurely into pensioners and there has been created a complicated internal market - the name for a device by which overhead costs are attributed in detail to individual broadcast programmes and whose effect is to impede creative work and demoralize those responsible for it. A couple of years from now, the BBC's managers will no doubt be telling those responsible for the new charter that they have taught the staff a humiliating lesson. The danger is that, in doing so, they may implicitly acknowledge that the $\mathrm{BBC}$ is no less (and no more) accountable than the British Army - to the government. 